\title{
The meanings of rural community according to nature of community livelihood in Brazilian Amazonia
}

\author{
Os significados de comunidade rural segundo a natureza dos modos de vida das \\ comunidades na Amazônia Brasileira
}

\section{Les définitions de communauté rurale selon la nature des modes de vie des communautés en Amazonie brésilienne}

\author{
Los significados de la comunidad rural según la naturaleza de los medios de \\ subsistencia de la comunidad en la Amazonia brasileña
}

\author{
Ana Maria de Albuquerque Vasconcellos ${ }^{1}$ \\ Mario Vasconcellos Sobrinho ${ }^{2}$ \\ Received in 29/03/2016; Revised and approved in 04/04/2017; Accept in 04/04/2017 \\ DOI: http://dx.doi.org/10.20435/inter.v18i2.1545
}

\begin{abstract}
The paper discusses the meanings of rural community according to nature of community livelihood in Brazilian Amazonia. Specifically, the paper stresses on the concept of community as a crucial aspect of the nature of diversity. The aim is to point out how development programmes interact and impact upon community's livelihoods without to take into account the meaning of rural communities they assume. The research data was gathered from four focus group in the municipalities of Concórdia do Pará, São Domingos do Capim, Irituia and Mãe do Rio, in Pará State. The paper shows that the understanding of rural community is a result of cultural, social and political construction and intrinsically linked to nature of community livelihood.
\end{abstract}

Key words: community; rural community; community livelihood.

Resumo: $O$ artigo discute os significados de comunidade rural na Amazônia brasileira tomando como referência a natureza e o modo de vida que as mesmas possuem. Especificamente, o artigo enfatiza o conceito de comunidade como um aspecto crucial da natureza da diversidade. O objetivo é mostrar como os programas de desenvolvimento interagem e impactam os modos de vida das comunidades sem levar em consideração o significado que essas comunidades rurais assumem. Os dados da pesquisa foram obtidos a partir de quatro grupos focais realizados nos municípios de Concórdia do Pará, São Domingos do Capim, Irituia e Mãe do Rio, no estado do Pará. O artigo mostra que a compreensão de comunidade rural é resultado da construção cultural, social e política da comunidade e está intrinsecamente ligada à natureza do modo de vida da mesma.

Palavras-chave: comunidade; comunidade rural; modo de vida comunitário.

Résumé: L'article traite les significations des communautés rurale d'Amazonie brésilienne en prenant comme références la nature et le mode de vie qui est le leur. Plus particulièrement l'article souligne le concept de communauté comme un aspect crucial dans la nature de la diversité. L'objectif est de montrer comment les programmes de développement interagissent et impactent les modes de vie des communautés sans prendre en considération ce que ces communautés rurales vivent. Les données de recherche ont été recueillis à partir de quatre groupes et réalisées dans les communes Concordio do Para, Sao Domingos do Capim, Irituia e Mae do Rio, dans l'Etat du Para. L'article montre que le compréhension des communautés rurales est le résultat d'un processus de construction culturelle, sociale et politique de la communauté et est intrinsèquement liée à la nature du mode de leur mode de vie.

Mots-clés: communaute; communaute rurale; mode de vie communautaire.

Resumen: El artículo aborda los significados de comunidad rural en la Amazonia brasileña considerando como referencia la naturaleza y la forma de vida que tienen. Especificamente, el artículo destaca el concepto de comunidad como un aspecto crucial de la naturaleza de la diversidad. El objetivo es mostrar cómo interactúan los programas de desarrollo y su impacto em los medios de vida de las comunidades, sin tener en consideración el significado que las comunidades rurales asumen. Los datos de la encuesta se obtuvieron a partir de cuatro grupos focales realizados en los municipios de Concórdia do Pará, São Domingos do Capim, Irituia y Mãe do Rio, en el estado de Pará. El artículo muestra que la comprensión de comunidad rural es

\footnotetext{
${ }^{1}$ Universidade da Amazônia (UNAMA), Belém, Pará, Brasil.

2 Universidade Federal do Pará (UFPA), Belém, Pará, Brasil.
} 
el resultado de la construcción cultural, social y política de la comunidad y está intrínsecamente ligada a la naturaleza de la forma de vida de la misma.

Palabras clave: comunidad; comunidad rural; modos de vida comunitaria.

\section{INTRODUCTION}

Local knowledge is an effective way to understand local people within their own frames of reference and according to their own assumptions and priorities (UPHOFF, 1992; BOWYER, 2006). The ignorance about the diverse features of the rural communities and their different interests has played a part in the inadequacy of the term community (BOWYER, 2006, p. 360). Chambers (1997, p. 41) demonstrates that rural people have capabilities, which earlier were little expressed and unsuspected by most outsiders such as government departments, NGOs or universities (CHAMBERS, 1997). To understand how development programmes impact upon community's livelihoods, this paper focuses on the concept of community as a crucial aspect of the nature of diversity.

Through of four focus group exercises used in this study, local people from the municipalities of Concórdia do Pará, São Domingos do Capim, Irituia and Mãe do Rio, all located in the Northeast of Pará State, were encouraged to debate their livelihood resources. These exercises were used to identify local people's understanding and beliefs about their livelihoods rather than only to describe the outcomes of these interactions. The key element was to recognise local people's values and what they considered obstructions in carrying out their activities in a development programme that they were involved ${ }^{3}$. One of the issues focused in the focus group carried by this research was to understand the meaning of community. The exercise was taken with a sample of 23 small-scale family-based agriculturists and community leaders of the four municipalities that make up the study. Each one participant represented a different family. Initially, four focus groups were used to debate the sense of community in general. In a second phase, the researchers conducted some interviews individually to explore some obscure points.

Focus groups also were conducted with local people to access information about the nature of diversity in community livelihoods. The exercise was to promote different interactions among those involved in the programme and to promote understanding of the significant diversity of the rural people in Brazilian Amazonia taking part. They are involved in a range of interactions and a number of similarities and differences can be observed within the notion of the community space. The focus on community issues was to shift the myths of community involvement in participatory approaches as a 'natural' social entity characterized by solidarity relations (CLEAVER, 2001, p. 44) that most of development programme adopt.

\section{THE MEANING OF RURAL COMMUNITY}

In spite of the heterogeneous features of the group, the research identified three groups of people to illustrate the complex spaces of community. The examples of communities were randomly selected to represent the different groups involved in Programme actions. This reveals a particular social feature of expressions of the identities and practices that are inherent to the diversity of society (SEN, 1999, p. 12).

\footnotetext{
${ }^{3}$ At the time that the study was conducted, the municipalities and their rural communities were involved in a socioenvironmental programme called Proambiente.
} 
The nature of community in the municipalities reveals that the term community is part of a highly complex process of identity construction. People's sources of meaning and experience are involved in a contradiction of plurality of individual and collective actors (CASTELLS, 1997, p. 23).

The term community was looked at from local people's understanding. Giddens (1991) argues that the local is where culture and knowledge are produced and where acts of reproduction of the social structure rule (GIDDENS, 1991, p. 32), and resources occur (THOMPSON, 2005, p. 27). In combination and over time, repeated patterns of social interaction among individuals constitute stable relationships resulting in the emergence of stable social structures (PEARCE, 2000; CASTELLS, 1997). They are the 'rules and resources, or sets of transformation relations, organized as properties of social systems' (GIDDENS, 1994, p. 25). It means that social structures play an important role in influencing the behaviour of members of an organization: who interacts with whom; who leads and who follows; what is noticed and what is ignored (CHAMBERS, 1997; PEARCE, 2000).

The complex and diverse nature of communities in Brazilian Amazonia requires the analysis of this term in a specific space of social relations regarding cultural, social and political issues (THIOLLENT, 2011). However, community as an 'elusive concept' changes to fit whatever conditions prevail, whilst Cohen (1982, p. 40-1) merely considers it to be 'a word rich in symbolism' that acts as a comforter to those who are trying to make change. The features of community are particularly significant to identify the cultural attitudes, values and beliefs from one generation to the next in a specific society. It means that community is a place of change as a result of cultural processes and knowledge production (DOVE, 2000; SCHONHUTH, 2002).

Participants regarding the nature of life in the pole of Rio Capim exemplify community as a space's symbolism, its ability to embody social and cultural values. For example, the term caboclo is attributed to local people in rural Amazonia (HARRIS, 1996) and also is strongly associated with Amerindians (BARROSO, 2006, p. 37) ${ }^{4}$. Local people have some similarity in terms of their livelihoods and social space. Caboclo is broadly applied in Brazil to reduce in importance the persons living in the 'back lands' or for anyone of a low social position. Additionally, the term caboclo can refer to people of varied racial composition. For Harris (1996, p. 14), 'caboclos are the mixed blood people who inhabit the Amazonia waterways'. In spite of a range of typologies to define local people, it is important to recognise that they have ability to survive and make a living in Amazonia. The term caboclo is widely used in Brazilian Amazonia as a category of social classification to refer to Amazonian peasants (LIMA-AYRES, 1992; HARRIS, 1996; SHANLEY, 2000). The debate gives an idea about the complexity of use of the term and the negative stereotypes of its colloquial use.

Harris (1996), for example, points out that most scholars who have written on caboclos have portrayed them as 'adaptations' to their historical and ecological conditions. In addition, caboclos have been characterised negatively, as non-tribal Amazonians, without an ethnic identity (HARRIS, 1996, p. 32-3). Harris's arguments refute the contingent nature of their lives, and show the ways in which caboclos are affirming a positive self-identity. A crucial change of perspective is needed, then, if aspects such as the 'denial' of and resistance to their alleged marginality are to be fully appreciated.

\footnotetext{
${ }^{4}$ See more in Barroso (2006, p. 37), who analyses the formation of the Amazonia caboclo culture into two different periods: (1) 1500-1850 with the arrival of the Portuguese to Amazonia and the rapid cultural exchange from which the caboclo emerged, and (2) 1850-1970 where there was an acculturation and absorption of subcultures into the caboclo system.
} 
Lima-Ayres (1992) also discusses the history of Portuguese occupation and ethnic domination of native Amerindians, which points to the origin of Amazonia's low class rural population. Caboclos are described as a peasant sector of the economy of the region, and their economy is regarded as two productive spheres, distinguished by different relations of production: production for direct use and commodity production (LIMA-AYRES, 1992; BARROSO, 2006).

Thus, the meaning of community in the municipalities demonstrates that they hold a rich biodiversity based on natural, social and cultural resources. Understandings and experiences of community space were further commented on among the focus group participants.

\section{THE DIVERSE NATURE OF THE COMMUNITY IN THE BRAZILIAN AMAZONIA}

In the first example that follows, the meaning of community demonstrates a strong sense of belonging, particularly in the sense of belonging to a family group and neighbourhood. At the same time, local people are interconnected by individual and/or collective practices that result in a range of social and cultural practices of self-help. Mutirão is one of the most important collective practices of self-help and of cultural identity in Amazonian communities. Mutirão is a form of collective work where people help each other at plantation and harvest time.

Taking account of the principle of Mutirao, members of a family share problems with other people that they are connected to by family ties. The term community is used to overcome individual family problems and is a method to provide help between families in the community especially for plantation, harvesting, house building and other forms of work.

The family groups are connected to create an economic capacity to promote income and well being for all members. It means that we live in a large family working together in a self-help way, mainly in the heaviest period. We help each other through the use of mutirão. ${ }^{5}$

I think that family is the most important thing [...] my parents always said that we should help each other for family purposes [...] we work together, we cultivate, we harvest, we pray [...]. ${ }^{6}$

The second example of community was encountered in communities of former slave backgrounds. In spite of the close features of this community, members of the community argue that engagement with the Development Programme has resulted in some changes in people's behaviours such as network formation, incorporation of new production activities, etc. The community of Cabo Verde in a Quilombo area is one such example. This community originated from the fight against slavery and the struggle for recognition of their rights in chapter 68 of the Brazilian Constitution. According to Almeida (1990), Quilombos [lands of black people] are those lands that were donated or acquired by former slave families, with or without legal documents (ALMEIDA, 1990, p. 229).

Communities are groups of people that are living in the same area with the same problems. People help each other in solidarity mainly when people are sick and they have no money to buy medicine. In this case, we call the curandeiro ${ }^{7}$ to make a medicine from herbs that can be collected in our quintais (yards). ${ }^{8}$

\footnotetext{
${ }^{5}$ Focus group with members of Vila do Galho in Concórdia do Pará.

${ }^{6}$ Interview with a 15-year-old-girl, Vila do Galho.

${ }^{7}$ Curandeiro is a person that is used in cases of illness and disease. The curandeiro uses different types of medicinal herbs from the Amazonia forest.

${ }^{8}$ Focus group with members of the community of Vila do Galho in Concórdia do Par.
} 
In the third example, the sense of community involves an interrelation among various issues such as religion, political and economic interests. Although this example of community presents a strong sense of belonging to a family group, they are the result of mixed kinship relations. While religion constitutes a basis for the constitution of community identity, religious practice does not constitute a basis for the formation of a symbolic identity at the level of the caboclo social category at large (LIMA-AYRES, 1992, p. 57-9).

Community is a group of families that live in a collective way and is linked by religion to solve common problems. Community is a different group of people that mixed for long generations and nowadays is linked by family relationships that are reinforced by religion and kinship. ${ }^{9}$

Everything started when the priest from the Catholic Church came along [...] he was a very kind person $[\ldots]$ he showed us that that was important to work together in a collective way, even we belong to a different community [family community] [...] the most important thing is to work for Jesus [...] if we help each other we work for Jesus [...]. ${ }^{10}$

These communities owe their origin to four centuries of miscegenation among peoples of African (slaves), indigenous and white backgrounds. This type of community predominates in most of the areas of the north-east of Pará, where people have different backgrounds but have lived together for long generations. The community of Vila do Galho (municipality of Concórdia do Pará), for example, has a diverse socio-cultural background from slaves, indigenous and white people that has been mixed and strengthened by inter-marriage. In spite of different backgrounds, they formed a sense of community under religious and political influence.

Here [Vila do Galho] people live together for long generations and they have interests that strengthen the group's family relations. For a long time we know that our families marry only between ourselves [...], but I do not want to marry any boy from our family because my children might be born with a disability. My uncle, for example, got married to my niece and their son was born without a hand. My other uncle got married to another aunt and the doctor said that probably their baby would not walk. At the present, we are more outward looking, because we have more contact with people from other communities. In my case, I want to marry a man from another community. ${ }^{11}$

In contrast to the previous example, the fourth example expresses a sense of community based on place where people are together as a result of the recent occupation. The nature of community is the result of a constant struggle for land in Brazilian Amazonia. The community is composed of people from different places from both inside and outside Amazonia. This community is formed by different groups of people who come from different places in Pará State and from the north-east of Brazil.

Here there is a community because we are living together with a common objective that is to improve our life and build up our families and friends. We came to this piece of land to rebuild our life [...] we wanted land to cultivate crops and to sustain our families [...] here we are. ${ }^{12}$

[...] we need to link our communities together to have the power to face government impositions [...] [is] the only way to confront the government to solve our land issues [...] we came from different parts of the north-east [of Brazil] looking for a better life [...] in the

\footnotetext{
${ }^{9}$ Definition from community members of Vila do Galho in the municipality of Concórdia do Pará.

${ }^{10}$ Inteview with a community leader, Vila do Galho.

${ }^{11}$ Interview with a 15 -year-old girl, Vila do Galho.

${ }^{12}$ Focus group with members of the municipality of Mãe do Rio.
} 
beginning we did not know each other but we were aware that we had the same problems [...] when FASE [NGO] came along and organised our thinking we were able to organise our association $[\ldots] .{ }^{13}$

The sense of community from these areas of occupancy is more complex because people have an insecure life from land pressures. Since human beings also depend on social and cultural systems, socio-cultural risks exist (KOENIG, 2006, 108). For example, interviews were conducted with people from the community of Jauira (municipality of Concórdia do Pará) to ask questions about their awareness of the risks in living in this type of community. One of the community members confidently said that despite all of the conflict that they faced during the land occupation, at the present they feel more confident with the support from local and national government.

In the beginning [when the land was occupied] we had problems to restart our life [...] it is hard to restart in a piece of land that is unknown to us, for the members of our family. But nowadays we have land and infrastructure services such as water, electricity, health and schools. ${ }^{14}$

They have improved their livelihood resources with the support of the Landless Movement and the Church Land Commission (CPT). They have also have support from other organisations linked with agriculture sector such as the Rural Workers' Unions, grassroots associations and others. Although often idealized, the local community has long been regarded as a vital resource for development efforts. Community development is based on the idea that local people, supported by external resources, can implement programmes that significantly reduce the extent of poverty and social deprivation (HALL; MIDGLEY, 2004, p. 73).

This social configuration came about from the politically-based community. Since the beginning of the 1980s, organisations linked with the Catholic Church and CONTAG ${ }^{15}$ acted in Amazonia in support of peasants and rural workers claiming their human and social rights (BARP; BARP, 2002, p. 263). The Catholic Church provided the space and support for poor, rural people to come together, both to support resistance to the federal, political model of Amazonia's development and to carry out small projects to improve their living situation (PEIXOTO, 1995, p. 80).

The Church followed the theory of liberation ${ }^{16}$ and created a new meaning of community that is directly linked to political positioning in favour of citizens' rights. The Church movement was a reaction to the regional modernization enforced by the government based on a model of capital accumulation. Although new technologies were provided for agricultural use, this model of 'modernization' of agriculture from the 1980s onwards, gave support to large landholders and/or the business sector and marginalized traditional peasants and rural workers. As a result, land concentration and a struggle for land emerged. In spite of the support from the Church and left-wing parties in the Amazonia rural area, violent land conflicts between large landholders and peasants occurred and are still present in the region.

\footnotetext{
${ }^{13}$ Focus group with members of the municipality of Mãe do Rio.

${ }^{14}$ Interview with member of the community of Jauíra.

${ }^{15}$ The Confederação Nacional dos Trabalhadores na Agricultura (National Federation of Agriculture Workers) provided great support to counteract the violence of the landowners against the rural workers in Amazonia.

${ }^{16}$ This theory of liberation comes from Paulo Freire.
} 
As Peixoto (1995, p. 89) points out, the Catholic Church played an important role in the construction of a cultural identity based on a mix between political and religious issues. From a political-religious perspective, the communities based on settlements have (re)created a cultural identity and accumulated knowledge that makes their sense of community different from previous representations. The struggle for land and also the social costs of the large public projects led to the emergence of peasants' unions and NGOs related to their cause (HALL, 1991; 2004).

The factors that form the meaning of community demonstrate the complex, diverse and dynamic nature of community livelihood in Brazilian Amazonia. It shows that the community is not a matter of institutionalised social arrangements; on the contrary it is expression of modalities of belongings (ALMEIDA, 2010). In local people's accounts of community, what is stressed is the fluid nature of community as an expression of modalities of belonging (DELANTY, 2003, p. 26). The meanings that people have about themselves reveal the diversity of cultural identity that is constructed and reconstructed as a knowledge accumulation process (BARROSO, 2006, p. 100). For example, local people in Vila do Galho have a diversity of occupations such as a crops cultivators, horticulturalists, fruit collectors, Brazil nuts collectors, fishermen and so on. They often earn a living from several of these activities simultaneously thus demonstrating the high level of diverse livelihoods in Amazonia.

However, the meaning of community is not rigid but fluid and open to change. The configuration of the communities points to the fact that local people's livelihoods are involved in diverse socio-cultural practices (WENGER, 2011). It demonstrates that people develop livelihood strategies according to the knowledge and skills based on experiences developed for long generations. However, the most important issue is to identify how Development programmes impact local people's knowledge and the cultural identity that comes from their relationship with their livelihood.

The establishment of communities created an agricultural society connected by roads to other colonies and development poles. The peoples that arrived in the roadside colonies are chiefly from outside Amazonia and thus they are carriers of other regional cultures with adaptive systems different from the traditional Amazonian caboclos. Food habits, socialisation methods, worldviews, technical experience and economic expertise all differ. The following figure summarises the meaning of community according to the nature of community livelihood. 

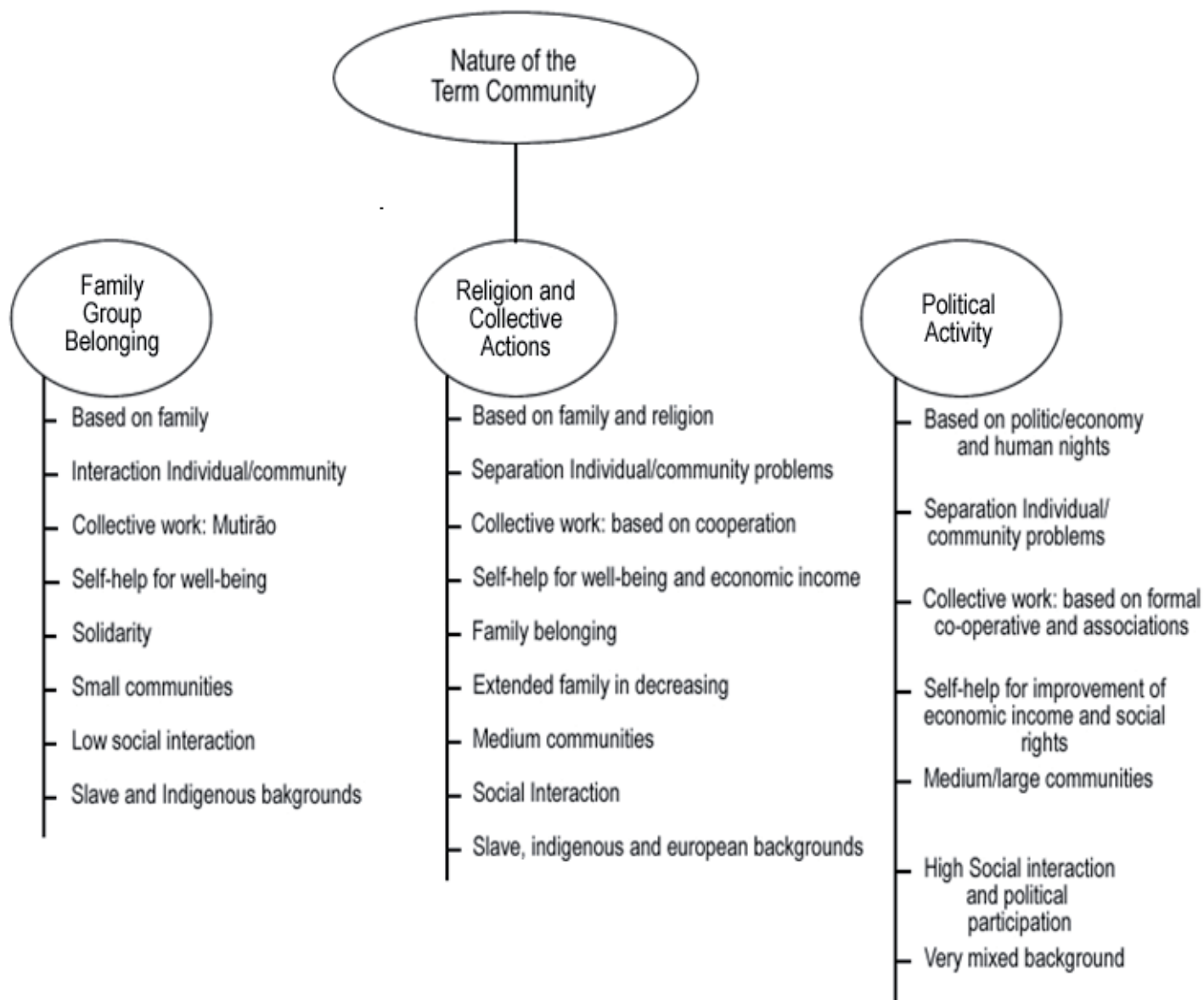

Figure 1- The Meanings of Community

Source: Field Work Research. Figure created by the authors from local people information.

The understanding of community knowledge as a result of cultural, social and political construction provides insights for discussing the impact of programmes on community livelihoods. Knowledge is involved in a social process that is not simply articulated in direct and immediate relations between people and environment but is also historically constructed through all sorts of social practices (KOTHARI, 2001, p. 141).

\section{FINAL REMARKS}

Programmes that contribute to the agricultural production of family-based small-scale agriculture and are supported by public investments and appropriate rural development policies based on socioenvironmental approach seem to be more efficient than large-scale agricultural programmes favoured by modernization theorists in the North-east of Brazilian Amazonia. The interaction of development programmes in the municipalities of Concórdia do Pará, São Domingos do Capim, Irituia and Mãe do Rio has been a positive feature. Under NGO intermediary practices, development programmes have interacted at many levels to involve local people in their pattern.

However, the establishment of development programmes is a complex task since they are involved in a range of interactions at local level. Local people's livelihood resources are connected, modelled and mediated by power relations and their meaning of community. The recognition that the expression of needs and priorities takes place in a context marked by power relations on the basis of cultural attributes is crucial to making any development programmes effective. 
Difficulties often arise in analysis of the space of interaction at local level of policy actions and its impact on local people. Through the use of focus group, local people have demonstrated their livelihood resources and debated their skills, abilities and knowledge that have been constructed for long generations. Communities' livelihoods resources and social, political and cultural interaction build up the diverse nature of communities. However, the local people's expectations rise proportionally when they are asked to take part in interactive participation programmes.

Local people are concerned that socioenvironmental programmes over stresses issues regarding forest conservation, distribution of the productive activities rather than focusing on land reform, land concentration and other issues that local communities demand and make one of their sense of identity.

The cultural features of the local communities have an important role in the policy space, in the diversity of cultural and social practices that are accumulated through a long process of acquisition. Local people are involved in a set of capabilities such as technologies, and local strategies that are matched between diverse actors. It is also concerned with identity, aspirations, structures and practices.

\section{REFERENCES}

ALMEIDA, M. G. Territórios de quilombolas: pelos vãos e serras dos Kalunga de Goiás - patrimônio e biodiversidade de sujeitos do Cerrado. Ateliê Geográfico, Goiânia, v. 4, n. 1, special edition, p. 36-6, 2010.

ALMEIDA, A. W. B. The state and land conflicts in Amazonia, 1964-88. In: GOODMAN, D.; HALL, A. (Ed.). Future of Amazonia: destruction or sustainable development? London: Macmillan, 1990. p. 226-244.

BARP, W. J.; BARP, A. R. B. Crisis and meditation in social and agrarian relations: the case of Acre. In: SAHA, S. K.; PARKER, D. (Ed.). Globalisation and sustainable development in Latin America: perspectives on the new economic order. Cheltenham: Edward Elgar Publishing, 2002. p. 250-276.

BARROSO, M. M. Waves in the forest: radio communication and forest livelihood in Brazilian Amazonia. 2006. Thesis (PhD in Social Politics)- London School of Economics and Political Science, England, 2006.

BOWYER, T. Social capital and health: a rural perspective. In: HUQUE, A. S.; ZAFARULLAH, H. (Ed.). Journal of International development governance. London: Taylor and Francis, 2006. p. 357-427.

CASTELLS, M. The power of identity, the information age: economy, society and culture. Oxford: Blackwell, 2010.

. The power of identity, the information age: economy, society and culture. Oxford: Blackwell, 1997 .

CHAMBERS, R. Whose reality counts? Putting the first last. London: Intermediate Technology Publications, 2002.

Whose reality counts? Putting the first last. London: Intermediate Technology Publications, 1997.

CLEAVER, F. Institutions, agency and the limitations of participatory approaches to development. In: COOKE, B.; KOTHARI, U. (Ed.). Participation: the new tyranny? London and New York: Zed Books, 2001. p. 36-55.

COHEN, A. Belonging: identity and social organisation in British rural cultures. Manchester: Manchester University Press, 1982.

DELANTY, G. Community. New York and London: Routledge, 2003.

DOVE, M. The life-cycle of indigenous knowledge, and the case of natural rubber production. In: ELLEN, R.; PARKERS, P.; BICKER, A. (Ed.). Indigenous environmental knowledge and its transformations: critical anthropological perspectives. Amsterdam: Harwood Academic Publisher, 2000. p. 213-51.

GIDDENS, A. Beyond left and right: the future of radical politics. Cambridge: Polity Press, 1994. Modernity and self-identity. Cambridge: Polity Press, 1991.

INTERAÇÕES, Campo Grande, MS, v. 18, n. 2, p. 21-30, abr./jun. 2017.7. 
HALL, A.; MIDGLEY, J. Social policy for development. London: Sage Publications, 2004.

. Developing Amazonia: deforestation and social conflict in Brazil's Carajás programme. Manchester: Manchester University Press, 1991.

HARRIS, M. People of the Amazon floodplain: kinship, work and sharing in a "caboclo" community near Óbidos, Pará, Brazil. 1996. Dissertation (Master of Economics and Political Science)- London School of Economics and Political Science, England, 1996.

KOENIG, D. Enhancing local development in development-induced displacement and resettlement projects. In: WET, C. (Ed.) Development: induced displacement- problems, policies and people. New York and Oxford: Berghahn Books, 2006. p. 105-140.

KOTHARI, U. Power, knowledge and social control in participatory development. In: Cooke, B. and Kothari, U. (Ed.). Participation: the new tyranny? London and New York: Zed Books, 2001. p. 139-152.

LIMA-AYRES, D. M. The social category caboclo: history, social organization, identity and outsider's social classification of the rural population of an Amazonian region (the middle Solimões). 1992. Thesis (PhD in Social Anthropology)- Cambridge University, Reino Unido, 1992.

PEARCE, J. Development, NGOs, and civil society: the debate and its future. In: PEARCE, J. (Ed.). Development, NGOs, and civil society. London: Oxfam, 2000. p. 15-43.

PEIXOTO, R. The making of political careers in southern Pará - Brazil. 1995. Thesis (PhD in Government) - University of Essex, Reino Unido, 1995.

SCHONHUTH, M. Negotiating with knowledge at development interfaces. In: SILLITOE, P.; BICKER, A.; POTTIER, J. (Ed.). Participating in development: approaches to indigenous knowledge. London and New York: Routledge, 2002. p. 139-161.

SEN, A. How does culture matter? In: RAO, V.; WALTON, M. (Ed.). Culture and public action. Stanford: Stanford University Press, 2004. p. 37-58.

. Development as freedom. Oxford: Oxford University Press, 1999.

SHANLEY, P. As the forest falls: the changing use, ecology and value of non-timber forest resources for Caboclo communities in eastern Amazonia. 2000. Thesis (PhD in Conservation and Ecology)- Kent University, Canterbury, 2000.

THIOLLENT, M. Action research and participatory research: an overview. International Journal of Action Research, German, v. 7, n. 2, p. 160-174, 2011. Available in: <http://wp.ufpel.edu.br/consagro/ files/2011/11/THIOLLENT-Michel-Action-Research-and-Participatory.pdf>.

THOMPSON, S. Trust, risk and identity. In: WATSON, S.; MORAN, A. (Ed.). Trust, risk and uncertainty. New York: Palgrave, 2005. p. 26-46.

UPHOFF, N. Learning from Gal Oya: possibilities for participatory development and post-Newtonian social science. Ithaca, New York: Cornell University Press, 1992.

WENGER, O. Communities of practice: a brief introduction. Oregon: Oregon University, 2011.

\section{About the authors:}

Ana Maria de Albuquerque Vasconcellos: Núcleo Socioeconômico, Universidade da Amazônia (UNAMA). E-mail: anamaria.vasconcellos@unama.br

Mario Vasconcellos Sobrinho: Núcleo de Meio Ambiente (NUMA), Universidade Federal do Pará (UFPA). Núcleo Socioeconômico, Universidade da Amazônia (UNAMA).E-mail:mariovasc@ufpa.br; mario.vasconcellos@unama.br 